UCRL-CR-130656

\title{
Digital Database Development and Seismic Characterization and Calibration for the Middle East and North Africa
}

\author{
M Batazangi \\ D Seber \\ E. Sandvol \\ C Oigien \\ F Gomez
}

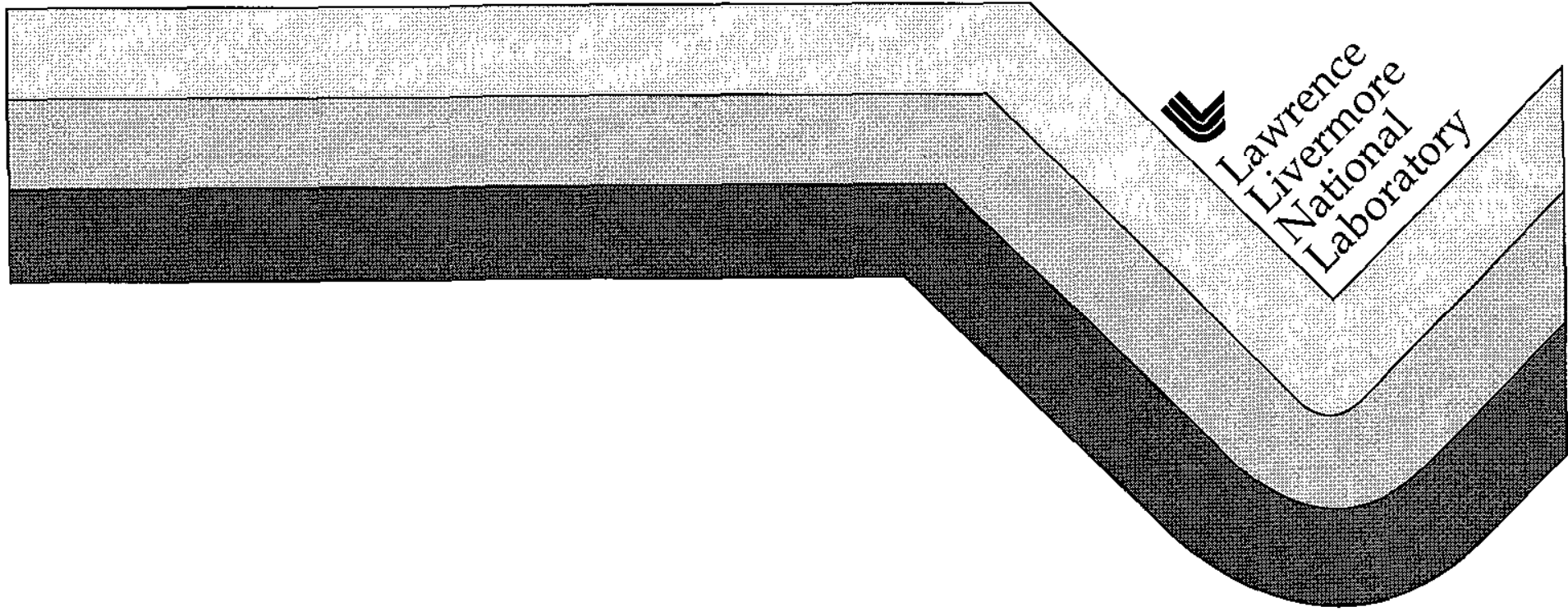




\section{DISCLAIMER}

This document was prepared as an account of work sponsored by an agency of the United States Government Neither the United States Government nor the University of California nor any of thei employees, makes any warranty, express or implied, or assumes any legal liability or responsibility for the accuracy, completeness, or usefulness of any information, apparatus, product, or process disclosed, or represents that its use would not infringe privately owned rights Reference herein to any specific commercial product, process, or service by trade name, trademark, manufacturer, or otherwise, does not necessarily constitute or imply its endorsement, recommendation, or favoring by the United States Government or the University of California The views and opinions of authors expressed herein do not necessarily state or reflect those of the United States Government or the University of California, and shall not be used for advertising or product endorsement purposes

Work performed under the auspices of the US Department of Energy by Lawrence Livermore National Laboratory under Contract W-7405-ENG-48 
Extension Report (Supplemental Agreement)

Contract F19628-95-C-0092, P00006

DIGITAL DATABASE DEVELOPMENT AND SEISMIC CHARACTERIZATION AND CALIBRATION FOR THE MIDDLE EAST AND NORTH AFRICA

Muawia Barazangi

Dogan Seber

Eric Sandvol

Christine Orgren

Francisco Gomez

Cornell University

Institute for the Study of the Continents (INSTOC)

Snee Hall

Ithaca, NY $14853-1504$

\section{Extension Report}

20 June 1997 - 23 December 1997 (Six Months Extension)

Submitted to:

DEPARTMENT OF ENERGY

Office of Non-Proliferation and National Security WASHINGTON, DC 20585

Lawrence Livermore National Laboratory

Sandia National Laboratories

31 March 1998 


\section{PART I: DIGITAL DATABASES FOR USE IN REGIONAL DISCRIMINATION OF EARTHQUAKES AND MINE-RELATED EXPLOSIONS IN NORTH AFRICA: A JOINT EFFORT WITH THE LLNL}

Ground truth information was provided to the Lawrence Livermore National Laboratory for experimental discrimination of mine-related explosions from earthquakes Remotely sensed data, knowledge of regional geology and tectonics, and other data sets were provided for two distinct projects at LLNL: (1) Detection of recent strip-mining activity using satellite remote sensing by Dr. William Pickles, and (2) Discrimination of minerelated explosions from earthquakes using regional waveform data by Dr David Harris and Dr William Walter. The primary contact person at Cornell for this activity was Francisco Gomez, a graduate student whose studies focus on the regional geology and tectonics of Morocco Two visits were made to LLNL by Francisco Gomez during Winter 1996 and Winter 1997, as well as one visit to Cornell by Dave Harris during the Summer of 1997

As part of this work, several data products were produced for use of the researchers at LLNL All of these have already been delivered to LLNL A summary of these data is given in Table 1

\section{Monitoring mining activity using remote sensing}

One of the largest mining operations in Morocco is the phosphate mining near Khouribga and Oued Zem (Figure 1) At these locations, phosphate is mined from extensive sedimentary layers through strip-mining As a result, mines and piles of tailings are clearly visible in satellite imagery and aerial photographs Documentation of each mine blast is kept at the ministry, and this is then available to researchers at Cornell Digital Landsat Thematic Mapper (TM) imagery (ca 1984) of the region was provided to LLNL for Dr. Pickles research, along with stereo aerial photographs acquired from the Division of Cartography in Moroccan Ministry of Agriculture Published topographic and geologic maps were also provided

Digital Landsat Thematic Mapper (TM) data were also provided to LLNL as needed, along with data processing algorithms for viewing with ERmapper digital image processing software Data were provided for several regions of northern Morocco and one area of southern Tunisia TM data have a spatial resolution of 285 meters and provide spectral resolution in the visible, near infrared and mid infrared The semi-arid to arid climate of much of North Africa is ideal for distinguishing lithological and soil variations

\section{Discrimination of explosions from earthquakes}

Other efforts were made to identify mines based on seismic cluster analysis, and once again, we provided additional information to LLNL researchers. These areas were in the region of Gafsa, Tunisia (Figure 2), and the Prerif and Khouribga/Oued Zem areas of Morocco (Figure 1) Landsat TM imagery (ca. 1986 and 1984, respectively) was 


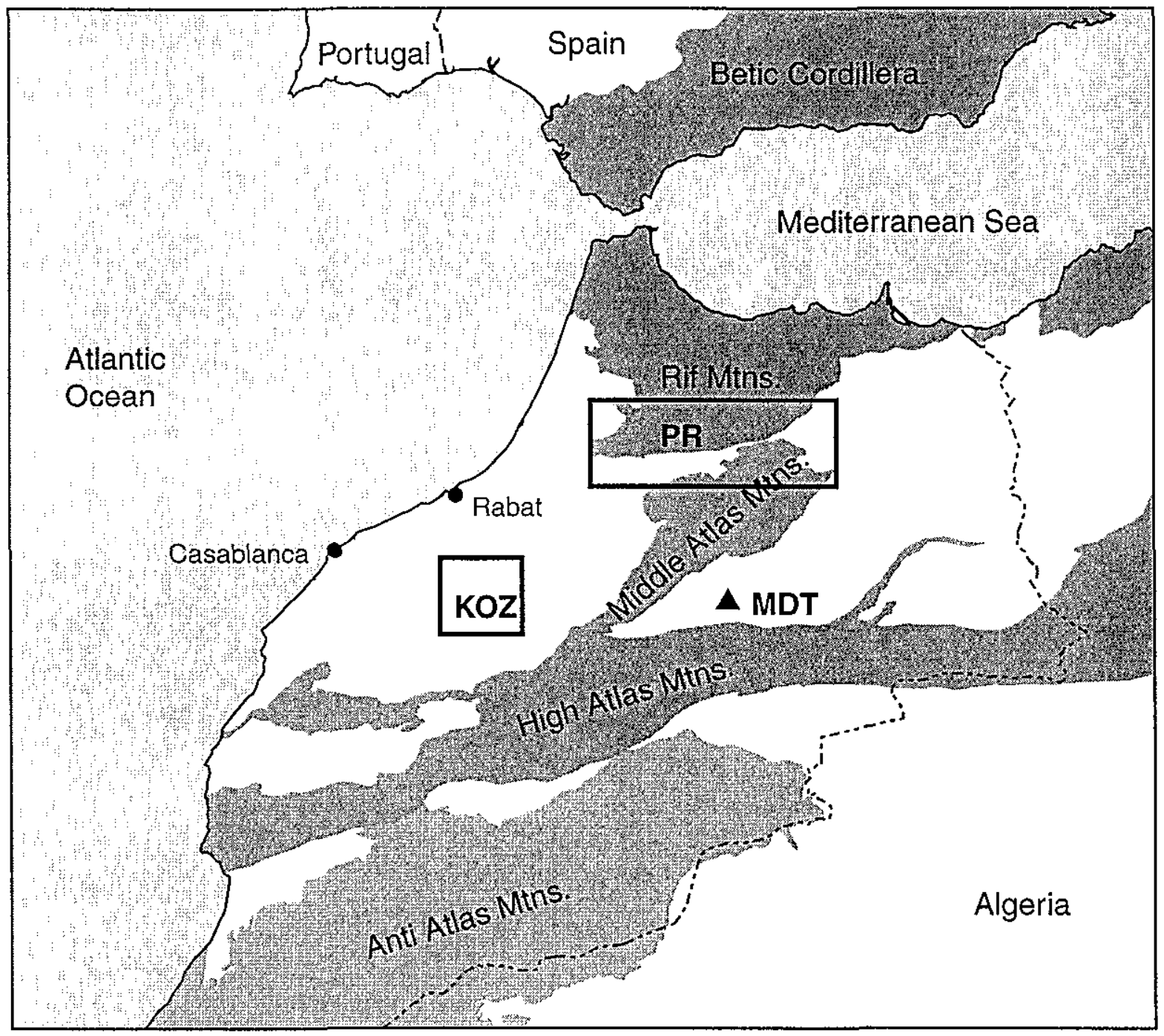

Figure 1. Map showing the regions of interest for seismic activity and mine correlation study. $\mathrm{KOZ}=$ Khouribga/Oued Zem mining areas; $\mathrm{PR}=$ Pre-Rif, $\mathrm{MDT}=$ Broadband seismic station 


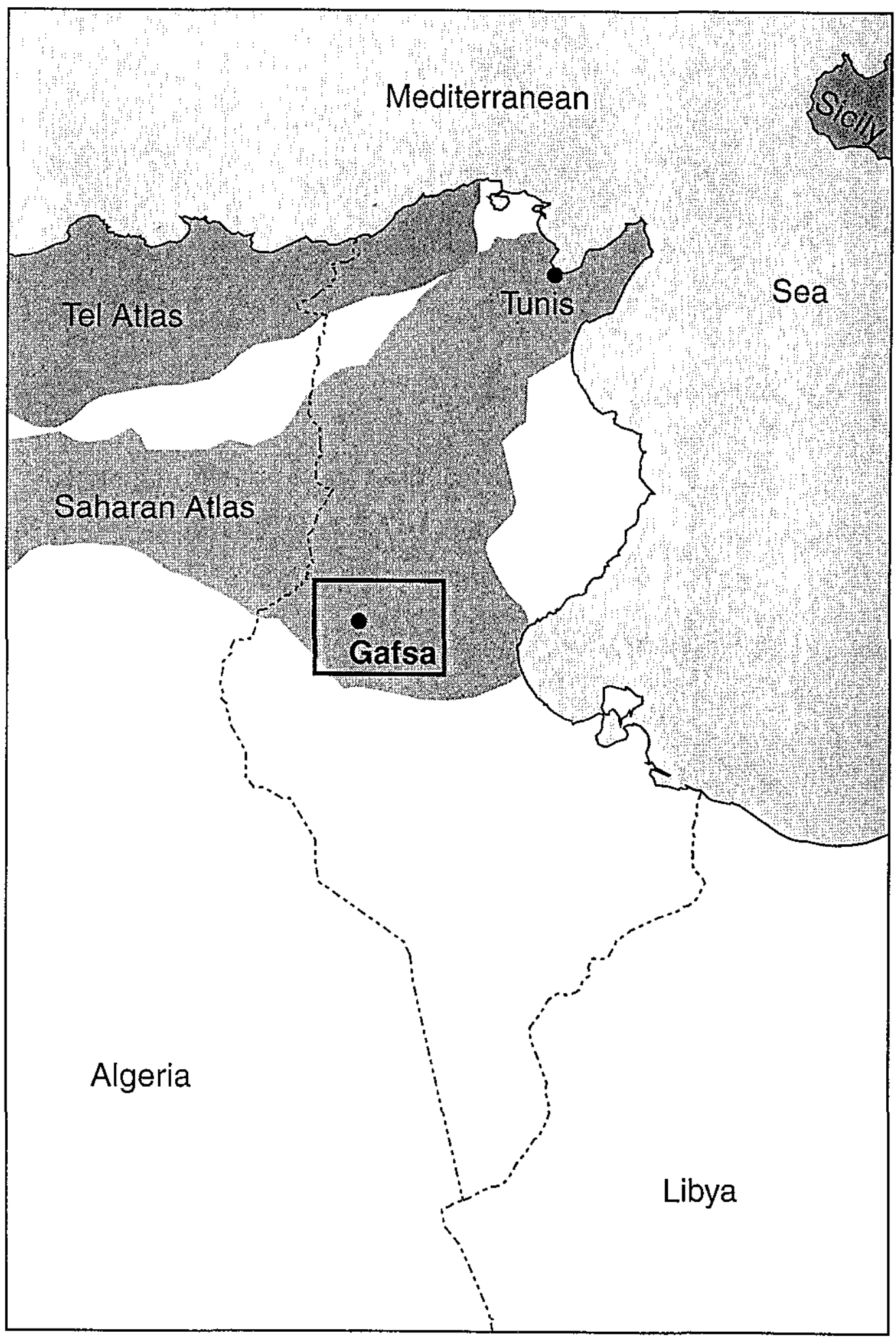

Figure 2. Map showing the location of the area of study in Tunisia. 
provided, along with digital image processing algorithms developed at Cornell for use with ERmapper image processing software

One of the key products was a digital database of mines in Morocco This was produced from information provided by the Moroccan Ministry of Energy and Mines listing all of the mines for metallic and non-metallic resources in the country. This database also includes information about the minerals being mined, the type of deposit, morphology, age, rock type, and mineralogical associations All of this information was entered into GEOID system for use with other data sets Locations of each mine are given to the nearest minute. The mines are described in more detail in Panorama de L'Industrie Miniere (Overview of the Mineral Industry) published by the ministry in 1990 The database does not contain information about periods of activity of the mines, but it is presumed that most in the list were active at the time of publication. This database is also included on the tape with the rest of the database package

Another product was a digital image file of the Carte Miniere et Energetique du Maroc (Mineral and Energy Map of Morocco), also published by the ministry in 1982 Although this information is dated, it is the only published map available and provides information about mine production The GIS database is more up-to-date than this map

Identifying phosphate strip mines corresponding with suspected explosions was successful with the satellite imagery due to the surface effects and the distinct spectral signature of phosphate mine tailings. The suspected events in the Pre-Rif region of Morocco, however, were not successfully correlated with mines or mine-like features in the satellite imagery. (It should be noted that the imagery is approximately 5 years older than the data used in the cluster analysis ) These regions involve mining that may employ different techniques

This effort is ongoing, and we will continue to provide assistance as needed. Dr. Harris and Dr. Walter plan to process more data in Morocco that overlaps with the operation of the Moroccan regional seismic network This should provide additional constraints on event locations 
Table 1. Table showing data provided to LLNL under this Suplemental Agreement of the contract

\begin{tabular}{|c|c|c|c|c|}
\hline Data Product & Date & Source & Format & Notes \\
\hline $\begin{array}{l}\text { Moroccan Mine } \\
\text { Database }\end{array}$ & 1990 & $\begin{array}{l}\text { compiled from } \\
\text { data provided by } \\
\text { Ministry of } \\
\text { Energy \& Mines }\end{array}$ & $\begin{array}{l}\text { ARC/INFO, } \\
\text { ASCII }\end{array}$ & \\
\hline $\begin{array}{l}\text { Mineral \& } \\
\text { Energy Map of } \\
\text { Morocco }\end{array}$ & 1982 & $\begin{array}{l}\text { Ministry of } \\
\text { Energy \& Mines }\end{array}$ & $\begin{array}{l}\text { scanned from } \\
12,000,000 \text { map, } \\
\text { in TIFF \& BIL } \\
\text { formats (w/ } \\
\text { Ermapper header } \\
\text { files) }\end{array}$ & \\
\hline $\begin{array}{l}\text { Topographic } \\
\text { maps of } \\
\text { Khouribga- Oued } \\
\text { Zem region }\end{array}$ & $1950 \mathrm{~s}$ & $\begin{array}{l}\text { Division of } \\
\text { Cartography, } \\
\text { Ministry of } \\
\text { Agriculture }\end{array}$ & $\begin{array}{l}1100,000 ; \text { paper, } \\
\text { scanned at LLNL }\end{array}$ & \\
\hline $\begin{array}{l}\text { Geologic Map of } \\
\text { Khouribga- } \\
\text { Oued-Zem }\end{array}$ & $1970 \mathrm{~s}$ & $\begin{array}{l}\text { Ministry of } \\
\text { Energy \& Mines }\end{array}$ & $\begin{array}{l}1.100,000 ; \text { paper, } \\
\text { scanned at LLNL }\end{array}$ & \\
\hline $\begin{array}{l}\text { Landsat } \\
\text { Thematic } \\
\text { Mapper (TM) } \\
\text { image data }\end{array}$ & $\begin{array}{l}1984 \text { (Morocco) } \\
1986 \text { (Tunisia) }\end{array}$ & $\begin{array}{l}\text { EROS Data } \\
\text { Center (USGS) }\end{array}$ & $\begin{array}{l}\text { BIL files with } \\
\text { Ermapper header } \\
\text { files }\end{array}$ & \\
\hline $\begin{array}{l}\text { Aerial } \\
\text { photographs of } \\
\text { Khouribga-Oued } \\
\text { Zem }\end{array}$ & 1990 & $\begin{array}{l}\text { Division of } \\
\text { Cartography, } \\
\text { Ministry of } \\
\text { Agriculture }\end{array}$ & 140,000 , paper & \\
\hline
\end{tabular}




\section{PART II. MIDDLE EAST AND NORTH AFRICA LOCAL COUNTRY SEISMIC BULLETINS}

We have organized all of the available earthquake locations, station locations, and phase data from local bulletins from the Middle East and North Africa region In all cases, except for one, the formats are the same fixed column, Fortran style ascii formats containing all of the data that we were able to extract from these files Unfortunately, due to differences in the methods of location from country to country, we left out some of the parameters which are unique to that country's particular network and are not in our estimation vital information We have, however, provided the original data that we have started from, so users can go back to the original data to extract these attributes These data are provided in the attached digital tape. It is also important to note that we have finished putting 31 years of ISC phase, event, and station data (totalling some 25 million phase readings) into $\mathrm{ARC} / \mathrm{NNFO}$ format as well as having incorporated it into our GIS menu system This database will provide an even more comprehensive database than the one we are providing here. We have also included phase readings from the Lebanese station BHL. This data file has not been reformatted since Lebanon does not currently produce earthquake location bulletins and hence we were not able to associate the phase picks with earthquakes using a local catalog

\section{Earthquake Catalogs}

The formats for the local/national earthquake catalogs for the Middle East are generally fairly similar Unfortunately most countries provide very little information concerning the error analysis The format we have used for these ascii flat files is uniform except for Turkey We have a catalog which has been compiled from a variety of networks in Turkey since 1985 . This is a very large catalog since it includes seismicity in western Turkey.

\section{Phase Data}

We have phase data for three countries: Syria, Morocco, and Saudi Arabia The data files with the format below have been created by extracting phase data only when the event coordinates were given. In the original phase files there are a large number of phase readings for unspecified and unassociated teleseismic and regional events We have also included phase data from Lebanon; however, the phase picks have not been associated with corresponding seismic events since Lebanon does not produce a national catalog

\section{Station Data}

Along with each of the phase data files we have given corresponding station files All stations referenced in the phase data files are present in these files. All of the station names are unique, that is, if a station changed location we have changed the name of that station name in the phase and station data files.

\section{Hardcopy Catalogs}

Cornell also has a large number of hardcopies of local earthquake catalogs and phase readings Within this database we have phase reading and earthquake location data for 
Israel from the period 1982 to 1991 We also have earthquake locations and phase data from Jordan for the years 1983 through 1991 in hardcopy form For Yemen we also have phase readings and local earthquake locations for the year 1996 We have phase readings as well as earthquake locations from the Kandilli Observatory seismic network in Turkey Upon request we would be happy to provide some hardcopies of some of these bulletins

All digital files of local country bulletins from the Middle East and North Africa region are included in the enclosed CD ROM disk. 


\section{PART III: METADATA}

It is important that data be accompanied by written documentation to enable accurate assessment of their reliability. Metadata, or "data about data", describe the content, quality, condition, source, history, and other characteristics of a dataset Without metadata, this information is known only to those who acquired or modified the data and the data lose value as the information is lost With metadata, prospective users can determine what data exist, the fitness of these data for their applications, and the conditions for accessing these data

To provide consistency for users with datasets from other sources, the Federal Geographic Data Committee (FGDC) Content Standard for Digital Geospatial Metadata was applied. Metadata standards facilitate data sharing through time and space The standard specifies the information content of metadata for a set of digital geospatial data; its purpose is to provide a common set of terminology and definitions for documentation related to these metadata The standard establishes the names of data elements and groups of data elements, the definitions of these data elements and groups, and information about the values that are to be provided for the data elements

The FGDC data elements are as follows

Identification Information - basic information about the data set Examples include the title, the geographic area covered, currentness, and rules for acquiring or using the data

Data Quality Information - an assessment of the quality of the data set Examples include the positional and attribute accuracy, completeness, consistency, the sources of information, and methods used to produce the data.

Spatial Data Organization Information - the mechanism used to represent spatial information in the data set Examples include the method used to represent spatial positions directly (such as raster or vector) and the number of spatial objects in the data set.

Spatial Reference Information - description of the reference frame for, and means of encoding, coordinates in the data set Examples include the name of and parameters for map projections or grid coordinate systems, horizontal and vertical datums, and the coordinate system resolution.

Entity and Attribute Information - information about the content of the data set, including the entities types and their attributes and the domains from which attribute values may be assigned Examples include the names and definitions of features, attributes, and attribute values.

Distribution Information - information about obtaining the data set Examples include a contact for the distributor, available formats, information about how to obtain data sets online or on physical media (such as cartridge tape or CD-ROM), and fees for the data 
Metadata Reference Information - information on the currentness of the metadata information and the responsible party Examples include currentness and information about the organization that provided the metadata

Metadata for Cornell data sets take about 350 pages when printed. The complete set of printouts are available in our Final Report However, with this extension report we provide a CD ROM with all Metadata in HTML format that can be viewed in any web browser Please see the enclosed CD ROM for individual Metadata for our data sets 


\section{Document Title (Unclassified):}

Digital Database Development and Seismic Chatacterization and Calibration for the Middle East and North Africa

LLNL Author Dave Harris Employee No 364682

Dept Geophysics and Global Security

Prgm Acct 5390-04

Ext $\underline{3-0617}$ L- 205

Additional Authors (and affiliations, if other than LLNL)

Extension Report (Supplemental Agreement) Contract F19628-95-C-0092, P00006

Cornell Univer sity.

Muawia Barazangi, Dogan Seber, Eric Sandovol, Christine Orgten, Francisco Gomez

DOE or WFO

Funding Office(s) (Note. Essential data)
Notify Bev Lovett

Ext $\quad 3.4537$

Employee Number 544598

\begin{tabular}{|c|c|c|c|c|c|}
\hline \multirow[t]{2}{*}{ 2. Type of Report: } & $\square$ AR & $\square \mathrm{ID}$ & $\square$ LR & $\square \mathrm{MA}$ & $\square$ PROP \\
\hline & $\square$ CONF $\square$ TB & $\square$ UR & $\square$ Web & $\square \mathrm{JC}$ & \\
\hline
\end{tabular}

Journal (Complete Name)

Conference (Complete Title (no acronyms), City, State, \& Date)

\section{Electronic Review and Release (If applicable, check one)}

$\square$ Library of the Future - Documents On-Line

File Name

File Format

File Size $\square$ Web Page

Final Uniform Resource

Locator (URL)

ReviewURL if different

Request
pointer from $\square$ Grapevine $\quad \square$ LLNL Public Web Site

Comments

\begin{tabular}{|l|}
\hline 4. Other Services \\
\hline Printing Instructions \\
\hline
\end{tabular}

Special Services

5. NUREG (Nuclear Regulatory Commission), If applicable:

Journal article specified in contract

$\square$ Yes $\square$ No

Report contains proprietary data

$\square$ Yes $\square$ No

NRC JCN

NRC Office or Division

Signature
Date
NRC approval of draft required

$\square$ Yes $\square$ No

Report contains a computer code listing

$\square$ Yes $\square$ No

NRC Tech Monitor

Signature Date 


\section{Author Approval}

Failure by the author to compietely fill out and sign this section can result in delays in processing your document

6a. LDRD Funding? $\square$ Yes $\square$ No Tracking\#

\section{6b. Patentable Matter}

In your opinion, does the document describe any new apparatus, new structure, combination of structures, new compositions of matter, ornew methods, or a new use of a known apparatus, structure, composition or method, or does the document describe any unexpected results?

Have you submitted to the LLNL Patent Office a written Record of Invention regarding any of the material in your document? $\square$ No $\square$ Yes (If yes, please provide)

Record of Invention File Number

Inventor's name(s)

Title

Have you made improvements not included in the preceding Record of Invention?

If yes, are these improvements described in your document?

7 Yes

No

$\square$ Yes $\square$ No

\section{6c. Cooperative Research and Development Agreement (CRADA)}

TCNO

Do you have the CRADA partner's permission to publish this document?

Yes $\square$ No

\section{6d. Designated Unclassified Subject Area (DUSA)}

This document's information is totally within the following DUSA

\section{6e. Export Control}

\section{Please list the name of the DUSA here}

Will the technology (information) be, or is it in the public domain, that is, is it generally accessible or available to the public, $\mathrm{g}$. already published, educational, included in patents, in public libraries, fundamental research, etc
$\square$ Yes $\square$ No
If no, an export control review is needed if this document is unclassified

\section{LLNL Author's Signature}

Date

\section{Division Approval}

Unlimited Distribution

[ Internal Online Distribution (LLNL only)

¿xternal Online Distribution (internet)

If no online distribution desired, please explain

Please check any applicable boxes
Laser Information

Source Code Listing

\section{Document Distribution}

\section{Limited Distribution} Sensitive Unclassified Information (SUI)

(State type of SUI for Limited/Controlled Distribution)

For information see

http //www !lnl gov/linl_only/tid/pub-services/ri-sui-sensub html

Non-DOE Sponsor

Received Release Authorization From
Name Keith K. Nakanishi Title Seismology Grp. Ldr.

8. Authorized Derivative Classifier (If DUSA, do not complete this section)
Title $\underline{U}$ Article/Report N/A Summary N/A

Basis for unclassified release

$\square$ Outside scope of AEA and EO

- Other Guide(s)

CG-ACVT-1
Abstract N/A

CG-DAR-1, Topic(s)
Nuclear Weapon Data

If NSI, Classified by

\section{Preliminary UCNI}

Exemption

\section{Guide, Source, or Original Authority}

As the reviewing $A D C$, the information in this document is within my technical competence and programmatic puniew and that I am familiar with the project work and classification guidance related to this document

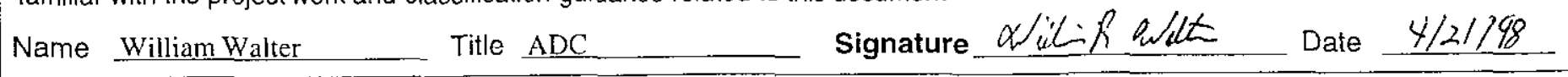




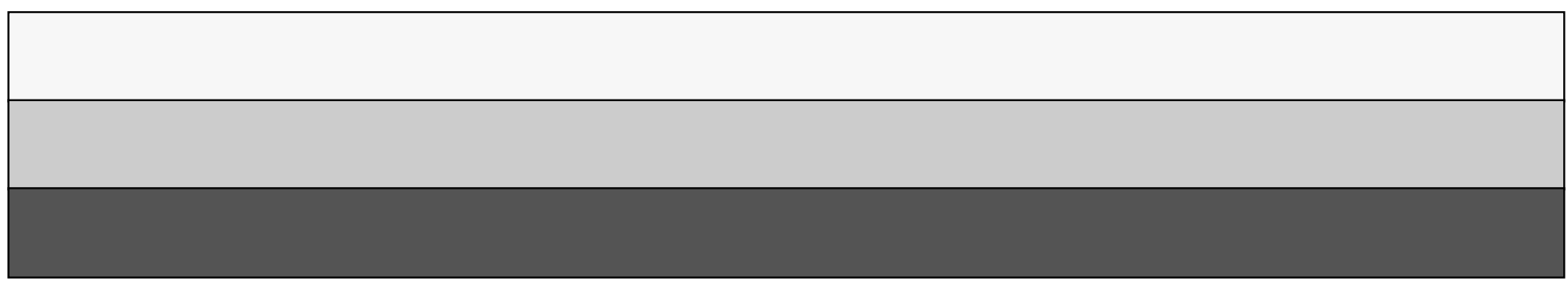

